NATURAL HISTORY NOTE

\title{
A new geographic record of the endangered Darwin's fox Lycalopex fulvipes (Carnivora: Canidae): filling the distributional gap
}

Un nuevo registro geográfico del amenazado zorro de Darwin Lycalopex fulvipes

(Carnivora: Canidae): completando el vacío distribucional

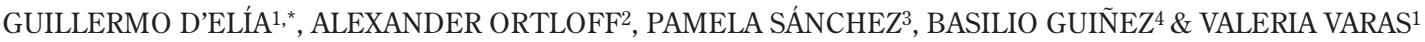 \\ ${ }^{1}$ Instituto de Ciencias Ambientales y Evolutivas, Facultad de Ciencias, Universidad Austral de Chile, \\ campus Isla Teja s/n, Valdivia, Chile \\ ${ }^{2}$ Escuela de Medicina Veterinaria, Facultad de Recursos Naturales, Universidad Católica de Temuco, \\ Manuel Montt 056, Temuco, Chile \\ ${ }^{3}$ Escuela de Ciencias Ambientales, Facultad de Recursos Naturales, Universidad Católica de Temuco, \\ Manuel Montt 056, Temuco, Chile \\ ${ }^{4}$ Departamento de Áreas Silvestres Protegidas, Corporación Nacional Forestal (CONAF), Francisco Bilbao 931, Temuco, Chile \\ *Corresponding author: guille.delia@gmail.com
}

Together with the cervid Pudu puda (Molina) and the microbiotherid Dromiciops gliroides Thomas, Lycalopex fulvipes (Martin), the Darwin's fox, is among the most symbolic animals of the Valdivian temperate forest. Of these three, Lycalopex fulvipes is the only endemic to Chile and the one with the most restricted known geographic distribution.

Darwin's fox was originally known from southeastern Chiloe Island $\left(43^{\circ} 23^{\prime} \mathrm{S}, 73^{\circ} 47^{\prime}\right.$ W), where Charles Darwin first collected it in December 6, 1832. Darwin (1839), in what now is a well-known passage of the "Voyage of the Beagle," narrated how he gathered that specimen: "In the evening we reached the island of S. Pedro, where we found the Beagle at anchor. In doubling the point, two of the officers landed to take a round of angles with the theodolite. A fox, of a kind said to be peculiar to the island, and very rare in it, and which is an undescribed species, was sitting on the rocks. He was so intently absorbed in watching their manoeuvres, that I was able, by quietly walking up behind, to knock him on the head with a geological hammer. This fox, more curious or more scientific, but less wise, than the generality of his brethren, is now mounted in the museum of the zoological Society." However, as will be indicated below, this species remains very elusive, both to the lay people and to scientists, even up to our days (in this regard it is interesting the comment given by Osgood 1943: 72-73). As such, Darwin's fox is considered as one of the rarest canids in the world (Macdonald \& Sillero-Zubiri 2004) and is categorized as critically endangered by the UICN (Jimenez et al. 2008).

On the basis of Darwin's specimen, Martin (1837) named fulvipes as a form of Vulpes. Subsequent to its original description, for a century and a half, mentions to fulvipes in the scientific literature were limited to report new Chiloean records (e.g., Osgood 1943) and mentions on taxonomic treatises usually referred to changes of its generic placement (e.g., Waterhouse 1839, Gray 1868, Cabrera 1931, Lannguth 1975) or specific status (e.g., Trouessart 1904, Housse 1953, Langguth 1969). Then, 153 years after its original description, Medel et al. (1990) reported a mainland population of $L$. fulvipes, in the Nahuelbuta National Park ( $37^{\circ} 47^{\prime}$ S, $72^{\circ} 58^{\prime}$ $\mathrm{W})$, about $600 \mathrm{~km}$ north of Chiloe. In the last two decades several studies on the natural history of Darwin's fox, based on Chiloean and Nahuelbuta populations, have been published (Elgueta et al. 2007, González-Acuña et al. 2007, Jaksic et al. 1990, Jiménez 2007, Jiménez et al. 1990, 2004, 2012).

A decade ago, Vilà et al. (2004) presented evidence of a possible additional population near Punta Chanchán $\left(39^{\circ} 21^{\prime} \mathrm{S}, 73^{\circ} 14^{\prime} \mathrm{W}\right)$, in the northern Pacific coast of the Region de Los Ríos. In addition to a putative observation 
of a live specimen of Darwin's fox by someone besides the authors, this evidence consists of the finding of a mitchondrial DNA (mtDNA) sequence that falls between a previously identified haplogroup of Lycalopex fulvipes (Yahnkee et al. 1996). This haplotype was recovered from a skin that was decorating the home of a resident of Punta Chanchán. However, as Vilà et al. (2004) acknowledged, the possibility that the fulvipes-like haplotype found at Chanchán is caused by introgression of fulvipes mtDNA into the genetic background of another species (particularly Lycalopex griseus, the chilla fox) cannot be ruled out with certainty. This is particularly possible in the light of the two available assessment of the genetic variation of Chilean foxes that shows that haplotypes recovered from specimens of Lycalopex griseus and Lycalopex culpaeus do not form monophyletic groups (Yahnke et al. 1996, Vilà et al. 2004). Finally, more conclusive was the recent report in a newspaper of camera trap-based records of $L$. fulvipes in two coastal localities of the Region de Los Ríos (the formal publication of these records is in progress; A. Farias, E. Silva-Rodriguez \& M. Sepúlveda com. pers. 2013).

We here report a new mainland locality record of Lycalopex fulvipes at Región de la Araucania, Comuna de Gorbea, Lastarria, Santa Rosa sector $\left(39^{\circ} 11^{\prime} \mathrm{S}, 72^{\circ} 46^{\prime} \mathrm{W}\right)$. This record is based on a specimen found dead; its necropsy indicated injuries compatible with a dog attack. This locality is about $160 \mathrm{~km}$ south of Nahuelbuta National Park, then constituting an intermediate population between the two previously unambiguously known localities of Lycalopex fulvipes. Lastarria, Santa Rosa is

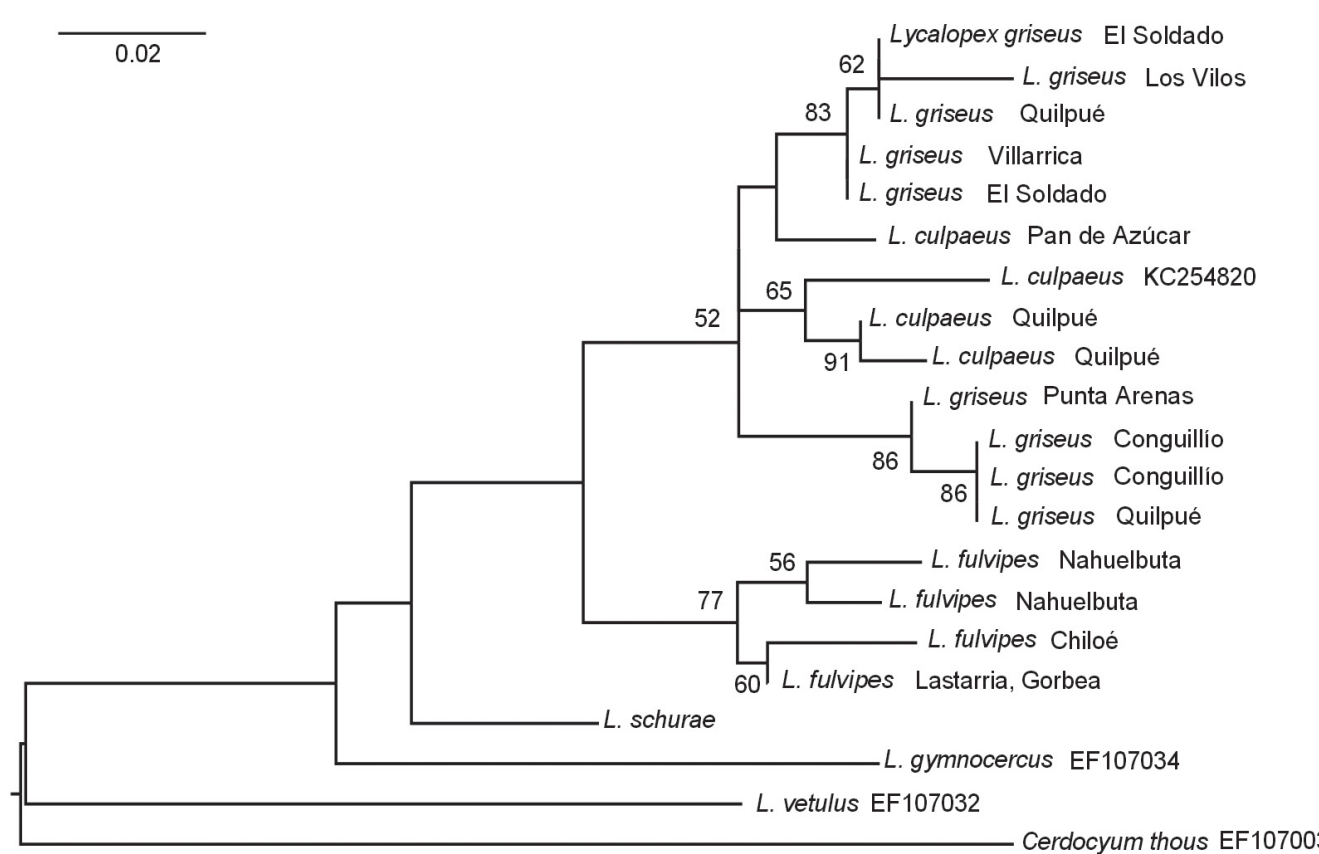

Fig. 1: Geneology (most likely tree; $\log \mathrm{L}=-852.83$ ) of a fragment of the mitochondrial control region of distinct canid specimens. Those sequences directly provided by Chris Yahnke lack GenBank accession numbers, but their precedence is indicated (see details in Yahnke et al. 1996). Those sequences downloaded from GenBank include accession numbers in their labels. Numbers by node correspond to Bootstrap support values (only those values above $50 \%$ are shown).

Genealogía (árbol más verosímil: $\log \mathrm{L}=-852.83$ ) de un fragmento de la región control mitocondrial de distintos especímenes de cánidos. Las secuencias provistas por Chris Yahnke carecen de número de acceso a GenBank, pero se indica su procedencia geográfica (ver detalles en Yahnke et al. 1996). Aquellas secuencias obtenidas de GenBank tienen el número de acceso en sus etiquetas. Los números en los nodos corresponden a valores de apoyo de Bootstrap (solo se muestran los valores mayores a 50 \%). 
about $60 \mathrm{~km}$ northeast of Punta Chanchán. The specimen that is the base of the new locality record presented here is under the custody of Servicio Agricola Ganadero, Región Araucania.

We sequenced a fragment of the mitochondrial control region of this specimen using primers Thr-L 15926 and DL-H 16340 (Vilà et al. 1999) and the following amplification conditions: 40 amplification cycles of $94{ }^{\circ} \mathrm{C}$ during $1 \mathrm{~min}, 48{ }^{\circ} \mathrm{C}$ during $1 \mathrm{~min}$ and $72{ }^{\circ} \mathrm{C}$ during $1 \mathrm{~min}$. The new sequence was submitted to GenBank (accession number KF693217) and analyzed with most of the DNA sequences of Chilean foxes generated and analyzed by Yahnke et al. (1996); these sequences were kindly provided by Chris Yahnke. The matrix was also expanded to include control region DNA sequences of Lycalopex that become available after the study of Yahnke et al. (1996). Accession numbers of those sequences gathered from GenBank are given in Figure 1. Alignment was done with Clustal X (Thompson et al. 1997) using the default alignment parameters and corrected by eye; the resulting matrix has 331 base pairs. Observed genetic divergences between pairs of haplotypes were obtained with MEGA 5 (Tamura et al. 2011). Genealogical relationships among haplotypes were conducted under a Maximum Likelihood approach (Felsenstein 1985) in MEGA 5 using a model of molecular evolution $(\mathrm{T} 92+\mathrm{G}+\mathrm{I})$ found with the same program. Nodal support was assessed by means of 1000 Bootstrap replicates (BS).

The genealogy $(\log \mathrm{L}=-852.83)$ shows that the haplotype from Lastarria falls within the clade $(\mathrm{BS}=77)$ of $L$. fulvipes haplotypes reported by Yahnke et al. (1996; including a discussion on the lack of monophyly of $L$. culpaeus and $L$. griseus; see also Guzman et al. 2009). As such, the genealogical analysis corroborates the morphological species determination of the specimen from Lastarria. Within the fulvipes clade, the haplotype from Lastarria appears sister $(B S=60)$ to that from Chiloe. Observed sequence divergence between the fulvipes haplotype from Lastarria and those from Nahuelbuta is 1.6 and $1.9 \%$, respectively, and with that from Chiloe is $1.7 \%$.

In the last few years, studies started to shed light on the amount and structure of the genetic variation of distinct Valdivian forest inhabitants distributed both in the mainland and in Chiloe, including lizards (e.g., Vera-Escalona et al. 2012), a marsupial (Himes et al. 2008), and one cervid (Fuentes-Hurtado et al. 2011; see also D'Elía 2012). However, given the small sample analyzed here we avoid advancing scenarios and comparisons based on the genealogical relationships uncovered. In the light of the increasing list of specimens and locality records of Lycalopex fulvipes that are being reported, an extensive phylogeographic study of Darwin's fox seems more feasible. Results of such study would provide much needed information to design an adequate conservation strategy for this species as well as allowing a better understanding of its recent evolutionary history.

ACKNOWLEDGMENTS: We greatly appreciate the assistance provided by Chris Yahnke who sent us the DNA sequences analyzed in his 1996 study. Financial support was partially provided by FONDECYT 1110737, MECESUP AUS0805 and MECESUP AUS1203.

\section{LITERATURE CITED}

DARWIN CR (1839) Journal of researches into the geology and natural history of the various countries visited by H.M.S. Beagle, under the command of Captain Fitzroy, R.N. from 1832 to 1836. Henry Colburn, London, UK.

D'ELÍA G (2012) Nomenclatural unawareness, or on why a recently proposed name for Chiloean populations of Pudu puda (Mammalia, Cervidae) is unavailable. Revista Chilena de Historia Natural 85: 237-239.

ELGUETA EI, J VALENZUELA \& JR RAU (2007) New insights into the prey spectrum of Darwin s fox (Pseudalopex fulvipes Martin, 1837) on Chiloé Island, Chile. Mammalian Biology 72: 179-185.

FUENTES-HURTADO M, JC MARÍN, D GONZÁLEZACUNA, C VERDUGO, F VIDAL \& J VIANNA (2011) Molecular divergence between insular and continental Pudu deer (Pudu puda) populations in the Chilean Patagonia. Studies on Neotropical Fauna and Environment 46: 23-33.

GONZÁLEZ-ACUÑA D, C BRICEÑO, A CICCHINO, SM FUNK \& J JIMÉNEZ (2007) First records of Tricodectes canis (Insecta: Phthiraptera: Trichodectidae) from Darwin's fox, Pseudalopex fulvipes (Mammalia: Carnivora: Canidae). European Journal of Wildlife Research 53: 76-79.

GUZMÁN JA, G D’ELÍA \& JC ORTIZ (2009) Variación geográfica del zorro Lycalopex culpaeus (Mammalia, Canidae) en Chile: implicaciones taxonómicas. Revista de Biología Tropical 57: 421-432.

HIMES C MT, GALLARDO MH \& KENAGY GJ (2008) Historical biogeography and post-glacial recolonization of South American temperate rain forest by the relictual marsupial Dromiciops gliroides. Journal of Biogeography 35: 1415-1424. 
JAKSIC FM, JE JIMENEZ, RG MEDEL \& PA MARQUET (1990) Habitat and diet of Darwin's fox (Pseudalopex fulvipes) on the Chilean mainland. Journal of Mammalogy 71: 246-248.

JIMENEZ JE (2007) Ecology of a coastal population of the critically endangered Darwin's fox (Pseudalopex fulvipes) on Chiloé Island, southern Chile. Journal of Zoology 271: 63-77.

JIMENEZ J \& E MCMAHON (2004) Darwin's fox Pseudalopex fulvipes (Martin, 1837). In: ZilleroSuribi C, MI Hoffmann \& DW Macdonald (eds) Canids: foxes, wolves, jackals and dogs. Status survey and conservation action plan. IUCN/SSC Canid Specialist Group: 50-55. IUCN/SSC Canid Specialist Group, Gland, Cambridge, UK.

JIMÉNEZ JE, M LUCHERINI \& AJ NOVARO (2008) Pseudalopex fulvipes. In: IUCN 2013. IUCN Red List of Threatened Species. Version 2013.1. URL: http://www.iucnredlist.org (accessed July 15, 2013).

JIMENEZ JE, PA MARQUET, RG MEDEL \& FM JAKSIC (1990) Comparative ecology of Darwin's fox (Pseudalopex fulvipes) in mainland and island settings of southern Chile. Revista Chilena de Historia Natural 63: 177-186.

JIMÉNEZ JE, C BRICEÑO, H ALCAÍNO, P VÁSQUEZ, S FUNK \& D GONZÁLEZ-ACUÑA (2012) Coprologic survey of endoparasites from Darwin's fox (Pseudalopex fulvipes) in Chiloé, Chile. Archivos de Medicina Veterinaria 44: 93-97.

MARTIN W (1837) Observations upon a new fox from Mr Darwin's collection (Vulpes fulvipes). Proceedings of the Zoological Society of London 1837: 11-12.

MEDEL R, J JIMENEZ \& F JAKSIC (1990) Discovery of a continental population of the rare Darwin's

Editorial responsibility: Marco A. Méndez

Received July 25, 2013; accepted September 21, 2013 fox, Dusicyon fulvipes (Martin, 1837) in Chile. Biological Conservation 51: 71-77.

TAMURA K, D PETERSON, N PETERSON, G STECHER, M NEI \& S KUMAR (2011) MEGA5: Molecular evolutionary genetics analysis using maximum likelihood, evolutionary distance and maximum parsimony methods. Molecular Biology and Evolution 28: 2731-2739.

THOMPSON JD, TJ GIBSON, F PLEWNIAK, F JEANMOUGIN \& DG HIGGINS (1997) The Clustal $\mathrm{X}$ windows interface: flexible strategies for multiple sequence alignment aided by quality analysis tools. Nucleic Acids Research 24: 4876-4882.

VERA-ESCALONA I, G D'ELÍA, N GOUIN, FM FONTANELLA, C MUNONOZ-MENDOZA, JW SITES JR \& PF VICTORIANO (2012) Lizards on ice: evidence for multiple refugia in Liolaemus pictus (Liolaemidae) during the Last Glacial Maximum in the Southern Andean Beech Forests. PLoS ONE 7: e48358.

VILA C, IR AMORIM, JA LEONARD, D POSADA, J CASTROVIEJO et al. (1999) Mitochondrial DNA phylogeography and population history of the grey wolf Canis lupus. Molecular Ecology 8: 20892103.

VILÀ C, J LEONARD, A IRIARTE, S O'BRIEN, W JOHNSON \& R WAYNE (2004). Detecting the vanishing populations of the highly endangered Darwin's fox, Pseudalopex fulvipes. Animal Conservation 7: 147-153.

YAHNKE C, W JOHNSON, E GEFFEN, D SMITH, F HERTEL et al. (1996) Darwin's fox: a distinct endangered species in a vanishing habitat. Conservation Biology 10: 366-375. 